\title{
Service Quality in Public Transport Services of the Provicial Intercity Transportation (AKDP) in East Java Indonesia
}

\author{
Sukesi ${ }^{1}$, Eddy Yunus ${ }^{1}$ \\ ${ }^{l}$ Lecturer at Faculty of Economics and Business, Universitas Dr. Soetomo - Surabaya, Indonesia \\ aminulah.assagaf@yahoo.com
}

\begin{abstract}
Evaluating and increasing the quality of public transport services, especially in the transport of AKDP in East Java is necessary. This study tries to (1) identify and analyze the quality of services; (2) to see the result of community satisfaction survey index (SKM); (3) The highest and lowest effects of the variables on the result of SKM index. The elements of assessment and qualitative descriptive analysis tools refer to KEP / 25 / M.PAN / 2/2004 on guidelines for the preparation of the Community Satisfaction Index and the Ministry decree No. 16 Year 2014, with nine (9) elements of the SKM assessment. This study determines the accidental sample by a random sampling technique that was done proportionally on 221 respondents.
\end{abstract}

Keywords: service quality; public transportation; satisfaction survey; consumer behavior

\section{Introduction}

The community is very influential and, for that reason, the government should also be responsible for the survival and it's supporting facilities for a decent life. They also should provide the infrastructure to support the operation of economic, social, educational facilities to get the decent society. They has to support the society with a good quality service systems and regulatory policies such as public transportation services, facilitating the mobility of the community activities. All are related to an economic growth with the mobility of the population, the hustle and productivity of available regional resources.

As stipulated in Law Number 22 Year 2009, a public transportation should meet the needs of being safe, safe, convenient, and affordable. Besides that, the price should also be affordable. As stated by Okeke et.al., (2015) that lower price paid by consumerscan positively affect the consumers' customer satisfaction. This effort is reinforced by Regulation of the Minister of Transportation of the Republic of Indonesia No. 29 of 2015 on the Amendment of the Minister of Transportation Regulation No. 98 of 2013 on Minimum Service Standards of Transportation of People with Public Vehicles in Route. It is stated that the obligations of public transport companies are to meet minimum service standards, including Security, safety, comfort, affordability, equality, and order.

The previous study by Intan Sulistyo W and Syela A F. Et al., (2015) found that the service standard currently did not fulfill the minimum service standard of transport.If the corridor is only served by one route, it is possibly difficult for the users to move due to the very or quiet routes. Of the 11 corridors currently available, there are two corridors only served by the companies, as the monopoly corridors such as in Surabaya - Ponorogo - Pacitan, and the Surabaya-Madiun-Magetan.

The above phenomenon makes public suffer for they are only served by very rare routes. A study by Sigit Haryanto (2010) with the dimensions: tangibles; reliability; responsiveness; assurance; empathy, found the people need a very high quality of service.The services should base on the users' expectations. But, all tend to be monopoly by certain companies and therefore in a bad quality service standard, being lack of safety, reliability, and comfort (Sutomo, 2008).

To improve the quality of service, the AKDP in East Java finds it necessary to conduct further study on this problems such as (1) howis the quality of service? (2) How is the 
community satisfaction survey index of the AKDP transport users of the services? (3) What variables have the highest and lowest effects on the results of the public satisfaction survey index of the AKDP transport users in the Surabaya - Ponorogo - Pacitan Corridor?

\section{Review of Literature}

Consumer behavior is very dynamic and tends to be adaptive, quickly adjust to the demand of the people who always need the public transport. Their demand is complex so that the government should create a good strategy for transport service quality. They need to be managed by the best managers in order to adapt to the users' expectation. In addition, a continuous performance valuation should also be done in order to narrow the gap between the expected and perceived service users. They should know the consumer behavior well, with a full understanding of the public habits. They even have to understand the people's movement and activities well. By doing so, the needs of consumers can be fulfilled.

The above effort can inevitably create a good image or a very long-term value, as required by the users, Sukesi (2013, II-12). It is also stated Assael (1995: 6) that failure to recognize consumers will result in costly mistakes. Disappointed consumers will leave to move on to other goods / services, so it is very simple to find consumers of this type, however, the impact on the company is significant if action is not taken immediately.

A consumer behavior is interesting, unique and dynamic attributesof the consumers. Kotler (2005: 201) describes it as individuals, groups, and organizations choose, buy, use and utilize goods, services, ideas or experiences in order to satisfy their needs and desires. It is an action getting, consuming, and consuming the products and services including the decision process, Husain Umar (2003: 50).It can be generalized that consumer behavior is a decision taken from an action, done through the process stages of previous thinking by individuals or groups or an organizational institution using the products or services.Service, in this case, is either a tangible or intangible provided by service providers. It can be individual or organizational organizations to meet the main needs or as the needs of supporting users. The marketers need to understand how customers evaluate their services (Cuningham, 2000).Thus, the issue of managing and measuringservice quality is a focus in this research.

Based on Law no. 25 of 2009, an activity or series of activities is the framework of fulfilling the needs of services in accordance with legislation for every citizen and citizen of the goods, services and/ or administrative services provided by public service providers. This public provider should also provide good infrastructure (Brystland and Curry, 2001). The Decree by the Minister of Administrative Reform No. 63 of 2003, public servies should inlcude (1) Simplicity, which means that the procedure of service is carried out easily, quickly, precisely, not complicated, easy to understand and easy to be implemented by people who request service; (2) Clarity and certainty (transparent), which contains the meaning of clarity and certainty about the following: Procedures of service; Terms of service, both technical requirements and administrative requirements; Work units and or officials authorized and responsible for providing services; Details of cost or service tariff and payment procedures; Schedule time of service completion; (3) Security; ( 4) Accuracy; (5). Responsibility; (6). Completeness of facilities and infrastructure; (7) Ease of access; (8). Discipline, courtesy and hospitality; (9) Convenience

\subsection{Standard of Public Services}

Public service standard is a product service performance contract, agreed by both parties: providers and users. Public service is the service in the implementation of Public Transport on the Road 
with Public Vehicles: buses or cars. They are the important factors as identified by Phaulley et. al (2006). Time efficiency should be taken into account by the providers. This is also referred to Johnson et. Al., (2008). that the reduction of time and effort that is required to complete the tasks (Johnson et al. 2008; Gurrido et. al., 2014, and De Onna et. al., 2013). More importatly, factors such as comfort, safety and cost, identified based on literature review and expert opinion (Jane et. al., 2014). In Indonesia, the indicators can be seen as stipulated in decree by the Minister of Transportation Number KM 35 Year 2003 concerning the Implementation of Public Transportation on Public Vehicles, in Article 19 stating that the Provincial Inter-Provincial Transport Service (AKDP) is conducted with the following characteristics:

- Have a fixed schedule, as stated in the hours of travel on the bus control card;

- The service of transportation that must be quick or efficient.

- Served by large or medium bus/car, for economic or non-economic service;

- Availability of passenger terminal of at least type B, at the beginning of departure, stopover, and destination terminal;

- Infrastructure based on AKDP Transport as specified in the route permit.

The Decree no. PM 10 of 2012 article 7, the AKDP Transportation consists of: 1. Safety 2. Safety, 3. Convenience, 4. Affordability, 5. Equity, and 6. Order. The logical consequences for AKDP Transporters in their implementation should provide facilities that meet service standards because; the service standard is one of the performance contracts that must be adhered to.

\subsection{Service Quality}

A good performance for its users or customers must be also met Fandy Tjiptono (2004). It is stated service quality is a dynamic resources covering the product of goods or services, human, process, and environment that meet user expectation (Sahfaq et.al. 2010). In providing quality services, it should also be met by the company that organizes public transport by basing such as on the regulaton by Kepmenhub Number (decree of Transportation Ministry) KM 35 Year 2003, the passengers of AKDP has rights and obligations:

- Being entitled to pay the agreed freight charges.

- With a receipt of payment to get a good service.

- Having the proof of payment and no additional payment or fees.

- Have a luggage facility that is not charged a maximum of $10 \mathrm{~kg}$ per passenger; excess baggage is set according to the operator agreement with the passenger.

Article 85: passengers are required to pay for the transportation fee as specified, and those who do not pay freight costs may be lowered by the crew of the vehicle at the nearest stop. In article 82, it is stated that in the operation of vehicles for public transport services, the driver of a public vehicle in charge shall meet the following requirements:

- Comply with the provisions in the field of transportation service and safety;

- Wearing company uniforms equipped with corporate identity and identification cards issued by the company

- Behave politely and kindly and n smoking during in-vehicle, no drinking alcohol, drugs, narcotics or other drugs;

- Comply with work time, rest period and change of driver in accordance with applicable provisions

In addition, any drivers should also have to be as the following: 
a) At the terminal, from the beginning of departure, stopover, until the destination and place of another specified place;

b) Get the passengers on from the front door but out through the back door in orderly manner, except for those who do not have double doors.

\section{Research Method}

This study is a quantitative and descriptive research approach. It a descriptive research, as referred to Sugiyono (2006). The researcher usedaccidental sample done by random sampling technique and with finally got 221 respondents. The research framework can be drawn in Figure 1.

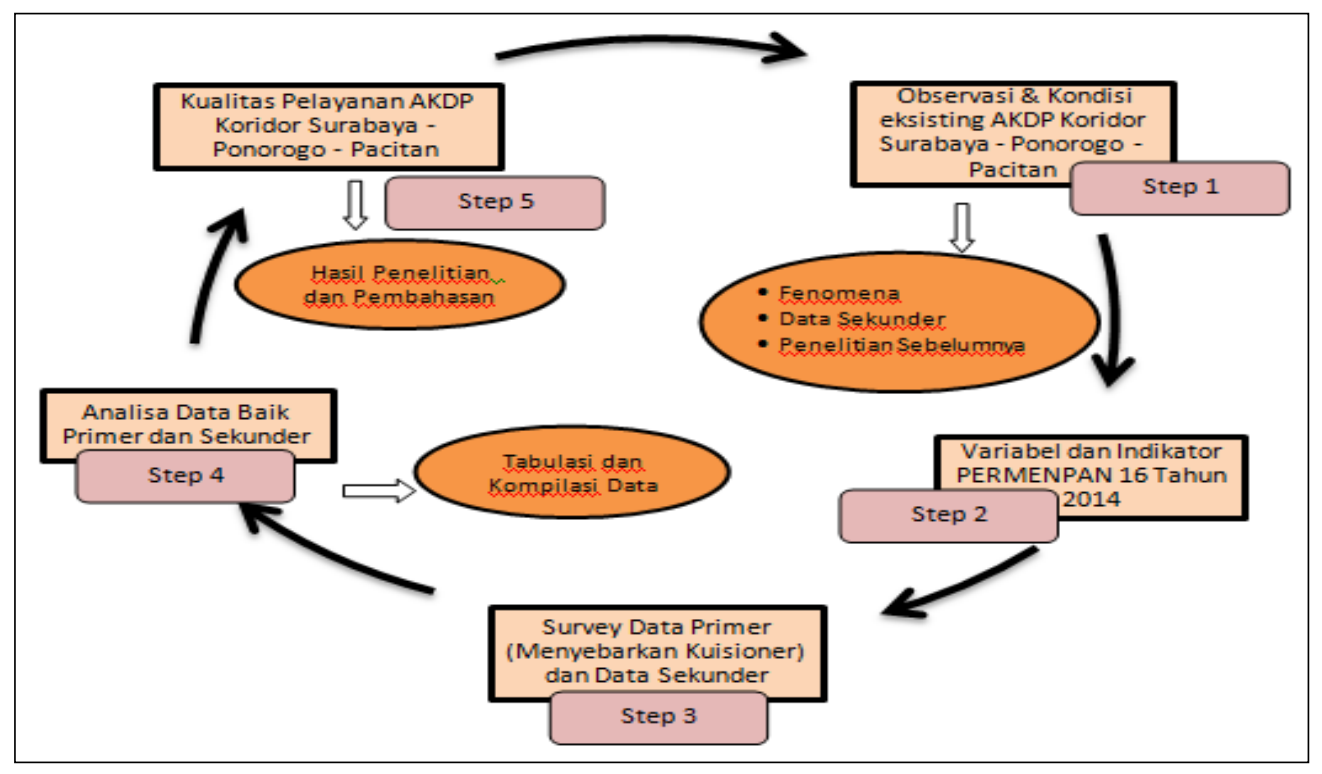

Figure 1: Research Framework

The primary data were collected from the field by survey method as referred to de Onna and Rocio (2014), for measuring service quality and Indriantoro \& Supomo (1999) related to an opinion, attitude, perception, experience, or characteristic of individual research subjects or groups. The secondary data were taken through documentation and library studies. The 9 variables are listed in Table 1.

Data Analysis: Using a weighted average score of 23 service indicators, and 9 assessment variables, refer to the following formula:

\begin{tabular}{|lc|}
\hline $\begin{array}{l}\text { Value of the } \\
\text { Mean Score } \\
\text { weighted }=\end{array}$ & Total Value \\
Total Elements
\end{tabular}$=\frac{1}{23}=0,0435$

Furthermore, to obtain the value of service quality index, this study used the weighted average value $(0.0435)$ with the following formula:

\begin{tabular}{|ccc|}
\hline $\begin{array}{c}\text { Index of } \\
\text { Quality } \\
\mathrm{P}=\end{array}$ & $\begin{array}{c}\text { Total value of Perception Per } \\
\text { Element }\end{array}$ & x Weighted \\
Value \\
\hline
\end{tabular}


To facilitate the interpretation of the assessment by using a range between 25 -100 which then the result of the assessment, it is converted with the following formula:

\section{Index of Service Quality (ISQ) x 25}

The conversion Interval of service quality index can be seen in Table 2

Table 1: Index of Service Quality (ISQ)

\begin{tabular}{|c|c|c|c|c|}
\hline $\begin{array}{c}\text { Perception } \\
\text { Value }\end{array}$ & $\begin{array}{c}\text { Interval } \\
\text { value of } \\
\text { ISQ }\end{array}$ & $\begin{array}{c}\text { Interval value } \\
\text { of Conversion }\end{array}$ & $\begin{array}{c}\text { Service } \\
\text { Quality }\end{array}$ & $\begin{array}{c}\text { Statements of } \\
\text { Service } \\
\text { performance }\end{array}$ \\
\hline 1 & $1,00-1,75$ & $25-43,75$ & $\mathrm{D}$ & Bad \\
\hline 2 & $1,76-2,50$ & $43,76-62,50$ & $\mathrm{C}$ & Fair \\
\hline 3 & $2,51-3,25$ & $62,51-81,25$ & $\mathrm{~B}$ & good \\
\hline 4 & $3,26-4,00$ & $81,26-100,00$ & $\mathrm{~A}$ & Very Good \\
\hline
\end{tabular}

Source: Kepmenpan No 25 Year 2014

\section{Results and Discussion}

\subsection{The respondet profile description}

Most of the respondents with the education level reaches $45.25 \%$, educated equivalent of undergraduate diploma, 82 respondents or $37.10 \%$, graduate education (S-1) 31 respondents $(14.03 \%)$, equivalent respondents of postgraduate (S2) 4 respondents of $1.81 \%$, junior educated only 4 respondents or $1.81 \%$. All can be seen in Figure 2.

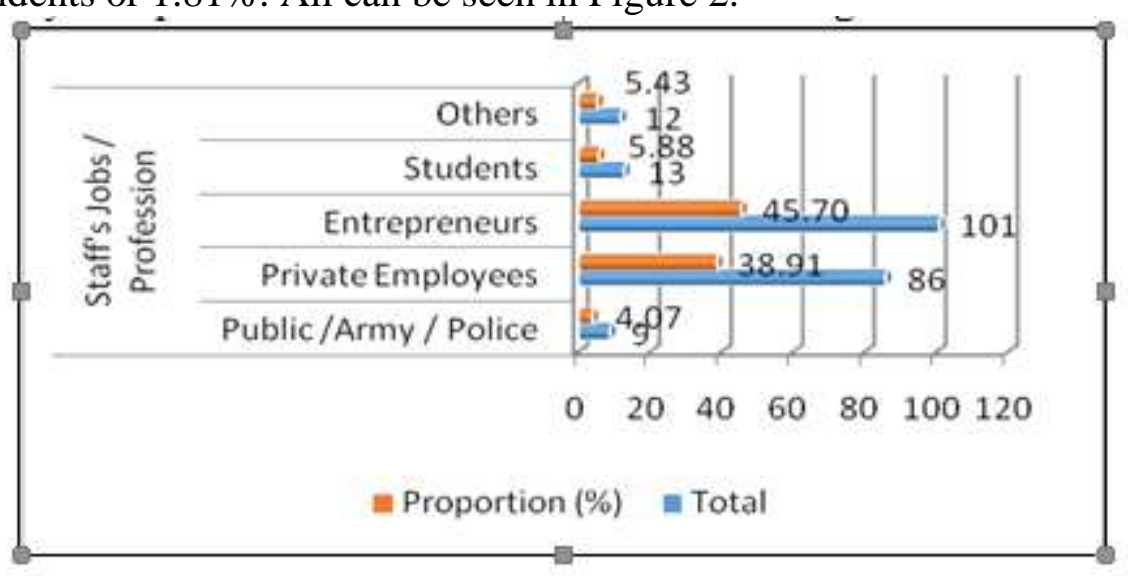

Source; Processed survey data 2016,

Figure 2: Respondent profile based on Job or profession

Most respondents are 88 private employees (38.91\%), 101 entrepreneurs / entrepreneurs (45.70\%), 9 of civil servant / army / police respondents (4.07\%) 13students (5.88\%), and 12 of others such as farmers, fishermen $(5.43 \%)$.

The results of service quality in Table 1. 
Budapest International Research and Critics Institute-Journal (BIRCI-Journal)

Volume I, No 4, December 2018, Page: 161-169 e-ISSN: 2615-3076(Online), p-ISSN: 2615-1715(Print) www.bircu-journal.com/index.php/birci emails: birci.journal@gmail.com

birci.journal.org@gmail.com

Table 2: Respondents' Characteristics

\begin{tabular}{|c|c|c|c|c|c|c|c|c|c|c|c|c|c|c|c|c|c|c|c|c|c|c|c|}
\hline Variable & \multicolumn{3}{|c|}{1} & \multicolumn{2}{|c|}{2} & \multicolumn{2}{|c|}{3} & \multicolumn{3}{|c|}{4} & \multicolumn{3}{|c|}{5} & \multicolumn{3}{|c|}{6} & \multicolumn{2}{|c|}{7} & \multicolumn{3}{|c|}{8} & \multicolumn{2}{|c|}{9} \\
\hline Indicator: & 1.1 & 1.2 & 1.3 & 2.1 & 2.2 & 3.1 & 3.2 & 4.1 & 4.2 & 4.3 & 5.1 & 5.2 & 5.3 & 6.1 & 6.2 & 6.3 & 7.1 & 7.2 & 8.1 & 8.2 & 8.3 & 9.1 & 9. \\
\hline Average & & 3.1 & 3.1 & 3.0 & 3.1 & 3.4 & 3.0 & 3.1 & 3.1 & 3.0 & 3.0 & 3.1 & 3.1 & 3. & 3.3 & 3.1 & 2.8 & 3.1 & 3.1 & 3.0 & 3.1 & 2.7 & 3.0 \\
\hline Value & . ד & 4 & 3 & 5 & 3 & 8 & 9 & 4 & 1 & 8 & 2 & 1 & 7 & 4 & 7 & 3 & 6 & 7 & 1 & 5 & 2 & 3 & 4 \\
\hline $\begin{array}{l}\text { Level of } \\
\text { Service } \\
\text { Quality }\end{array}$ & A & B & B & B & B & A & B & B & B & B & B & B & B & A & A & B & B & B & B & B & B & B & B \\
\hline
\end{tabular}

Source: The processed Primary Survey Data 2016

Based on the 9 elements of service performance appraisal with 23 indicators, there are 4 indicators of 3 variables with rating category A (very good), and the remaining 19 indicators of category B (good). The assessment of the community satisfaction survey index (SKM) is 78.27 with service quality in category B (good) with an average value of 3.13. and, some variables have the highest and lowest impact on the results of IKM are presented in Table 1.

\begin{tabular}{|c|c|c|}
\hline 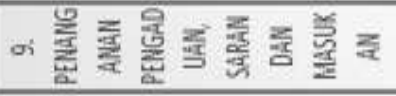 & $\begin{array}{l}9.2 \text { RESPONSE/RESPONSE OF MANAGEMENT... } \\
9.1 \text { THE AVAILABILITY OF COMPLAINTS... }\end{array}$ & $\begin{array}{l}75.94 \\
68.29\end{array}$ \\
\hline \multirow{5}{*}{ 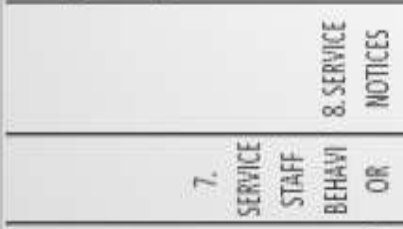 } & 8.3 THE FLEET'S CREW'S CONCERN FOR... & 77.93 \\
\hline & 8.2 COMFORT IN FREIGHT OR FLEET OF AKDP BUS & 3.05 \\
\hline & 8.1 SECURITY CONDITIONS WITHIN THE AKDP... & 3.11 \\
\hline & 7.2 THE FRIENDLINESS AND COURTESY OF THE... & 3.17 \\
\hline & 7.1 KNOWLEDGE OF THE DRIVER AND CREW IN... & 2.86 \\
\hline \multirow{3}{*}{ 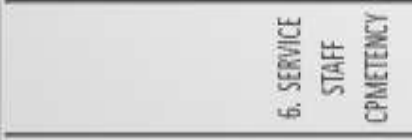 } & 6. 3 CREW SKILLS SUPPORTERS DRIVER (PORTER,... & 3.13 \\
\hline & 6.2 KNOWLEDGE OF THE DRIVER AND CREW IN... & 3.37 \\
\hline & 6.1 CONFORMITY OF CARRYING CAPACITY... & 3.40 \\
\hline \multirow{3}{*}{ ル } & 5.3 AVAILABILITY OF SUPPORTING FACILITIES IN... & 3.17 \\
\hline & 5.2 CONFORMITY BETWEEN THE NUMBER OF... & 3.11 \\
\hline & 5.1 CONFORMITY BETWEEN THE RATE... & 3.02 \\
\hline \multirow{3}{*}{ 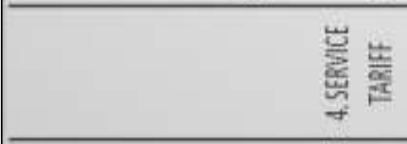 } & 4.3THE FAIRNESS OF THE RATE CHARGED & 3.08 \\
\hline & 4.2 TRANSPARENCY / CLARITV OF APPLICABLE... & 3.11 \\
\hline & 4.I COMPATIBILITY OF TRAVEL TIME & 3.14 \\
\hline \multirow{2}{*}{ 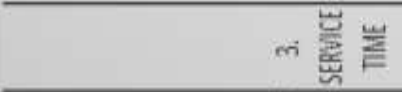 } & 3.2 CLARITY OF INFORMATION ON SCHEDULE... & 13.09 \\
\hline & 3.1 COMPATIBILITY BETWEEN CREW... & 3.48 \\
\hline \multirow{2}{*}{$\sim$ 岁总崖 } & 2.2 CONFORMITYBETWEEN THE APPLICABLE... & 3.13 \\
\hline & 2.1 FULFILLMENT OF MINIMUM SERVICE.. & 3.05 \\
\hline \multirow{3}{*}{ 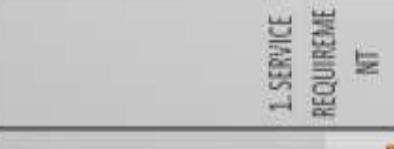 } & 1.3 THE TECHNICAL FEASIBILITY OF THEAKDP... & 3.13 \\
\hline & 1.2 CLARITY OF INFORMATION OF THE LANES... & 3.14 \\
\hline & 1.1 KEIELASAN INFORMASI JURUSAN $Y$ ANG... & 33.40 \\
\hline & 口Average Value/Criterium & 0020.090 .060 .0080 .00 \\
\hline
\end{tabular}

Source: the processed Survey Data 2016

Figure 3: Results of Community Satisfaction Survey Index - Average Per Assessment of the Variable

It indicates that the service quality is very good, and can be described as the following: Based on Figure 3, the variable with the highest value is the time service variability (3) on the clarity indicator of operational schedule information (3.1) with the value of 86.99 (A = very good). This is certainly a positive perception, because the respondents get the certainty of bus 
departure schedule according to the schedule that has been determined by the management. The next highest value of service provider is their competence (6) for the bus crew and drivers' knowledge indicator in recognizing the service route (6.1) with a value of $85.07(\mathrm{~A}=$ Very Good). That is, the respondents feel that the drivers and the bus crew experienced enough to recognize the service route, because the service route, especially the Ponorogo route toward Pacitan through the hills and mountains and the path winding up and down the mountain. They thought that such routes require special skills for driving the bus for them.

Service requirement (1) on clarity indicator of department information served (1.1) is 84, 95 (A $=$ very good). The respondents feel being greatly assisted by the information in the board announcement list of departures. The information for them is very helpful to prospective passengers, especially people who are just traveling by bus.

The crew skills and other supports (the porter, conductor and so on) and safety (6.2) are with the value of 84.28 ( $\mathrm{A}=$ very good). The respondents give a reason that it is because this corridor through the mountain area especially Ponorogo-Pacitan routes. They think it needs special skill of the bus crew (driver, porter and conductor) in facing emergency condition (especially in rainy season), as well as the potential for broken bridges and other natural disturbances.

The service qualities that get less value are as the following:

Handling the complaints that is (9) of the AKDP transport. They have the lowest value, especially on the availability of handling the complaints of suggestions, and inputs with a value of $68.29(\mathrm{~B}=\mathrm{Good})$ with an average value of 2.73 .

The managers of the AKDP bus have not yet provided an adequate means of handling the complaints and suggestions even though the ticket given to passengers and the seats have been addressed by the bus management or managers. Yet, the address of the handling, especially, has no specific input and suggestion feedback. A number of passengers transported with the existing capacity are with the value of the SKM index of 75.57 (B = Good) with an average rating of 3.02. They argued that, on certain routes, the buses carry passengers beyond the existing capacity, especially in many industrial lines such as Surabaya-Mojokerto-Jombang.

\section{Conclusion}

Based on the results and analysis, it can be concluded as follows.

First of all, the quality of service on AKDP Transport Corridor for Surabaya - Ponorogo Pacitan, in majority is B (good) with the evidence of 9 elements of service quality variables with 23 indicators. In this, there are 4 indicators from 3 variables with category A (very good), and the remaining 19 indicators from 6 variables with category B (good).

Secondly, the assessment of 78.27 with service quality is also in category B (good) with an average value of 3.13 .

The third deals with the variables that have the highest and lowest influence as follows: It is Time of service (3) on indicators of clarity of operational schedule information (3.1); service delivery competencies (6) on the bus crew and driver's knowledge indicators in recognizing service routes (6.1); the terms of service (1) on the information clarity indicator of the department served (1.1); and the skill driver support crew (porter, Conductor, etc.) and maintaining the safety (6.2). 
The forth is the variable that has the lowest influence that is a complaints of inputs, suggestions and inputs of the community or users of the AKDP transport, the indicators of availability of means of handling the complaints of suggestions and inputs (9.1); the product service specifications (5) especially the suitability of the number of passengers transported by the existing capacity (5.1).

This study suggests that the passengers standing should be given facilities such as the handles or hand grips; the tariff should be more transparent. This study also suggests that the facilities in the bus should be optimally functioned such as the TV, tape recorder, feasible C, the amplespace seats, and no street vendors.

\section{References}

Ahmad Ashfaq, et.al., 2010. “An empirical investigation of Islamic banking in Pakistan based on perception of service quality" in African Journal of Business Management Vol. 4(6), pp. 1185-1193, June 2010

Assael (1995), “Consumer Behavior and Marketing Action". Fourth Edition, PWS-Kent Publishing Company, Boston.

Brystland A and Curry A. 2001. "Service Improvement in Public Service Using SERQUA “ in Managing Service Quality Volume 11, Number 6, 2001, pp: 389-401

Cunningham, Laurence. 2000. Methodological Triangulation in Measuring Public Transportation Srvice Quality, in Transportation Journal, Fall. 2000.

De Oña, Juan, et al. 2013. "Perceived service quality in bus transit service: a structural equation approach." Transport Policy 29 (2013): 219-226.

De Oña, Juan, and Rocio de Oña. "Quality of service in public transport based on customer satisfaction surveys: A review and assessment of methodological approaches." Transportation Science 49.3 (2014): 605-622.

Fandy Tjiptono (2004), Manajemen Pemasaran Jasa, Yogyakarta: Andi Offset

Garrido, Concepción, Rocío De Oña, and Juan De Oña. "Neural networks for analyzing service quality in public transportation." Expert Systems with Applications 41.15 (2014): 68306838.

Intan Sulistyo W, Syela A F. dkk "Kajian Kinerja Operasional Bus Antar Kota dalam Provinsi (AKDP) Kelas Ekonomi AC dan Kelas Eksekuif Trayek Malang - Surabaya”. Jurnal Mahasiswa Jurusan Teknik Sipil Vol 1, No 2015.

Jain, Suresh, et al. "Identifying public preferences using multi-criteria decision making for assessing the shift of urban commuters from private to public transport: A case study of Delhi." Transportation Research Part F: Traffic Psychology and Behaviour 24 (2014): 60-70.

Johnson, D. S., F. Bardhi, and D. T. Dunn. 2008. Understanding how technology paradoxes affect customer satisfaction with self-service technology: The role of performance ambiguity and trust in technology. Psychology and Marketing 25: 416-43. doi:10.1002/mar.20218.

Undang-Undang Nomor 25 Tahun 2009 tentang Pelayanan Publik;

Undang-Undang Nomor 22 Tahun 2009 tentang Lalu Lintas dan Angkutan Jala

Peraturan Menteri Perhubungan Republik Indonesia Nomor PM 29 Tahun 2015 Tentang Perubahan Atas Peraturan Menteri Perhubungan Nomor 98 Tahun 2013 Tentang Standar Pelayanan Minimal Angkutan Orang Dengan Kendaraan Bermotor Umum dalam Trayek 
Keputusan Menteri Pendayagunaan Aparatur Negara (Kepmenpan) Nomor 16 Tahun 2014 tentang Pedoman Survei Kepuasan Masyarakat Terhadap Penyelenggaraan Pelayanan Publik

Keputusan Menteri Perhubungan Nomor KM 35 Tahun 2003 tentangPenyelenggaraan Angkutan Orang Di Jalan dengan Angkutan Umum

Keputusan Menteri Perhubungan No. PM 10 Tahun 2012 pasal 7 Tentang Standar Minimal Angkutan Massal Berbasis Jalan

Keputusan Menteri Pendayagunaan Aparatur Negara Nomor 63 Tahun 2003 tentang Pedoman Umum Penyelenggaraan Pelayanan Publik.

Keputusan Menteri Pendayagunaan Aparatur Negara Nomor 16 Tahun 2014 tentang Pedoman Survey Kepuasan Masyarakat Terhadap Penyelenggaraan Pelayanan Publik

Keputusan Menteri Pendayagunaan Aparatur Negara Nomor: KEP/25/M.PAN/2004 tentang Pedoman Umum Penyusunan Indeks Kepuasan Masyarakat Unit Pelayanan Instansi Pemerintah.

Kotler, P., (2005). Manajamen Pemasaran. Jilid 1 dan 2. Jakarta: PT. Indeks Kelompok Gramedia.

Nur Indriantoro, \&. Bambang Supomo (1999), Akuntan Metodologi Penelitian Bisnis untuk Akuntansi dan Manajemen, Yogyakarta: Penerbit BPFE.

Okeke TC, et.al., 2015. "Service Quality Dimensions and Customer Satisfaction with Online Services of Nigerian Banks" in Journal of Internet Banking and Commerce.

Paulley, Neil, et al. "The demand for public transport: The effects of fares, quality of service, income and car ownership." Transport Policy 13.4 (2006): 295-306.

Sigit Haryono, 2010, “ Analisis Kualitas Pelayanan Angkutan Umum (Bus Kota) di Kota Yogyakarta'. Jurnal Administrasi Bisnis, Volume 7, Nomor 1 Juli 2010

Sutomo, 2008. Prioritas Angkutan Umum untuk Menggapai Keberlanjutan, Jurnal Transportasi Vol. 8 Edisi Khusus No. 3 Oktober 2008.

Sugiyono. 2006. Statistika untuk Penelitian. Bandung : Alfabeta

Umar H, 2003. Pengukuran tingkat kepuasan Pelanggan. Jakarta: Gramedia Pustaka Utama. 